\title{
PENGARUH PENGGUNAAN MODEL PEMBELAJARAN ASSURE TERHADAP PENINGKATAN PRESTASI BELAJAR IPAANAK TUNALARAS KELAS IV DI SLB E BHINA PUTERA SURAKARTA TAHUN AJARAN 2017/2018
}

\author{
Destri Wahyu Utami, Mohammad Anwar, Hermawan \\ Pendidikan Luar biasa, Fakultas Keguruan dan Ilmu Pendidikan, \\ Universitas Sebelas Maret Surakarta \\ Email : destriwahyu21@gmail.com
}

\begin{abstract}
Abstrak
Penelitian ini bertujuan untuk mengetahui pengaruh penggunaan model pembelajaran ASSURE terhadap peningkatan prestasi belajar IPA anak tunalaras kelas IV di SLB E Bhina Putera Surakarta tahun ajaran 2017/2018. Penelitian menggunakan metode eksperimen dengan one group pretest-posttest design, yaitu sekelompok subjek dikenai perlakuan dalam jangka waktu tertentu dan pengaruh perlakuan diukur dari perbedaan antara pengukuran awal (pretest) dan pengukuran akhir (posttest). Subjek penelitian yaitu seluruh siswa kelas IV SLB E Bhina Putera Surakarta yang berjumlah 5 orang siswa. Teknik pengumpulan data menggunakan tes, yaitu tes objektif berbentuk pilihan ganda. Data yang terkumpul selanjutnya dianalisis dengan teknik analisis uji peringkat bertanda Wilcoxon (Wilcoxon Sign Rank Test).

Hasil penelitian bedasarkan analisis data yang dilakukan, diketahui nilai Zhitung adalah -2,027 dengan Asymp. Sign (2-tailed) 0,043 pada taraf signifikan ( $\alpha$ ) 0,05 atau $5 \%$. Dengan demikian, dapat disimpulkan bahwa penggunaan model pembelajaran ASSURE berpeengaruh terhadap peningkatan prestasi belajar IPA anak tunalaras kelas IV di SLB E Bhina Putera Surakarta tahun ajaran 2017/2018..
\end{abstract}

Kata Kunci: model pembelajaran ASSURE, prestasi belajar IPA, tunalaras

\begin{abstract}
This research aims to determine of the influence of using ASSURE learning model toward increase of the science learning achievement of children with emotional and behavioral disorder in fourth grade at SLB Bhina Putera Surakarta 2017/2018 academic year. The research used experimental method with one group pretest-posttest design, which is the subject was exposed to get treatment for a certain period of time and the effect of treatment was measured from the diverification of pretest and posttest. The subject of research was all of fourth grader of SLB E Bhina Putera Surakarta consisting of 5 students. The data were collected by using testing. Then, the collected data was analyzed by using Wilcoxon Sign Rank Test.

The result of research based on the analyzed data, it is shown that the $\mathrm{Z}$ score is 2,027 with Asymp. Sign (2-tailed) 0,043 at significant level $(\alpha) 0,05$ or $5 \%$. Thus, it can be concluded that the using of ASSURE learning model is influential toward increase of the science learning achievement of children with emotional and behavioral disorder in fourth grade at SLB Bhina Putera Surakarta 2017/2018 academic year.
\end{abstract}

Keywords: ASSURE learning model, science learning achievement, emotional and behavioral disorder 


\section{PENDAHULUAN}

Pendidikan tidak hanya diperuntukkan bagi kalangan tertentu. Semua warga negara Indonesia berhak mendapatkan pendidikan tanpa mengenal suku, adat, ras, agama, dan bentuk kelainan yang dialami. Seperti diatur Undang-Undang Sistem Pendidikan Nasional Pasal 5 ayat 1 dan 2 No. 20 Tahun 2003 yang menjelaskan bahwa:

Ayat 1 "Setiap warga Negara mempunyai hak yang sama untuk memperoleh pendidikan yang bermutu" dan ayat 2 "warga Negara yang memiliki kelainan fisik mental/ intelektual, sosial, dan emosional berhak memperoleh pendidikan khusus" (Direktorat Pembinaan Sekolah Luar Biasa, 2009: 3).

"Pendidikan khusus (Pendidikan Luar Biasa) merupakan pendidikan bagi peserta didik yang memiliki tingkat kesulitan dalam mengikuti proses pembelajaran karena kelainan fisik, emosional, mental, sosial, dan/atau memiliki kecerdasan dan bakat istimewa" (Direktorat Pembinaan Sekolah Luar Biasa, 2009: 3). Untuk itu penyelenggaraan pendidikan khusus berupa pendidikan luar biasa merupakan salah satu upaya pemerintah untuk meningkatkan pelayanan pendidikan anak berkebutuhan khusus. Anak Berkebutuhan Khusus (ABK) merupakan anak yang mengalami gangguan atau hambatan dalam perkembangan fisik maupun mentalnya, sehingga mereka membutuhkan perhatian dan layanan khusus. Salah satu anak berkebutuhan khusus yang mengalami hambatan atau gangguan yaitu anak tunalaras.

Tunalaras merupakan istilah yang sering digunakan dalam dunia pendidikan khusus. Menurut Algozzine, dkk (1981) dalam Sunardi (1995: 9) berpendapat bahwa "anak tunalaras adalah anak yang secara kondisi dan terus-menerus masih menunjukkan penyimpangan tingkah laku tingkat berat yang mempengaruhi proses belajar, meskipun telah menerima layanan belajar dan bimbingan seperti halnya anak lain. Somantri (2006: 139), juga menjelaskan bahwa anak tunalaras adalah anak yang mengalami gangguan emosi dan tingkah laku sehingga anak mengalami kesulitan menyesuaikan diri dengan baik terhadap lingkungannya dan dapat mengganggu situasi belajarnya.

Gangguan emosi dan tingkah laku anak tunalaras mengakibatkan anak kurang dapat menyesuaikan diri dengan baik terhadap lingkungannya. Ketika dalam pembelajaran anak tunalaras sering kali menunjukkan perilaku yang menyimpang seperti hiperaktivitas, mengganggu teman, susah duduk tenang, susah berkonsentrasi, dan sering ramai sendiri ketika pembelajaran sedang berlangsung. Gangguan emosi dan tingkah laku anak tunalaras tersebut dapat mengganggu proses pembelajarannya di sekolah.

Berdasarkan hasil studi pendahuluan yang dilakukan, minat belajar inilah yang kurang terlihat pada anak tunalaras, karena anak tunalaras memiliki hambatan dalam memusatkan perhatiannya sehingga di dalam kelas mereka akan cepat mudah bosan, tidak aktif dalam 
pembelajaran dikarenakan pada saat guru menerangkan perhatian mudah teralihkan, enggan untuk bertanya karena rasa malas dan rasa kurang percaya diri, tidak tahan belajar dalam waktu yang relatif lama sehingga mendorong anak untuk keluar kelas saat pelajaran sedang berlangsung. Selain itu, anak tunalaras mengalami masalah-masalah lain seperti masalah dalam mata pelajaran Ilmu Pengetahuan Alam. Dikarenakan dalam mata pelajaran Ilmu Pengetahuan Alam diperlukan kemampuan memahami dan menghafalkan istilah-istilah

Menurut pendapat Moerdiani, 1987 (dalam Effendi, 2006), "Bahwa rendahnya prestasi belajar anak tunalaras di sekolah diduga karena kehilangan minat belajar dan konsentrasi belajar yang rendah akibat gangguan emosi.

Salah satu model pembelajaran yang dapat digunakan dalam peningkatan prestasi belajar anak tunalaras yaitu model pembelajaran Analyze learner characteristics, State performance objectives, Select, methods, media, and materials, Utilize materials, Requires learner participation, Evaluate and revise atau yang dikenal dengan sebutan ASSURE. Model ASSURE ini dikembangkan oleh Smaldino, dkk, pada tahun 2005. Rincian huruf demi huruf tidak hanya merupakan penjabaran dari singkatan kata ASSURE, namun penjabaran huruf-huruf dari kata ASSURE ini merupakan rincian langkah-langkah dalam membuat perancangan pembelajaran. Model pembelajaran ini lebih berorientasi kepada pemanfaatan media dan teknologi dalam menciptakan proses dan aktivitas pembelajaran yang dinginkan. Hal ini selaras dengan pendapat Smaldino, dkk (2011: 111) "Model ASSURE dirancang untuk membantu para guru merencanakan mata pelajaran yang secara efektif memadukan penggunaan teknologi dan media di ruang kelas".

Model ASSURE telah difokuskan pada perencanaan pembelajaran untuk digunakan dalam situasi pembelajaran di dalam kelas secara aktual. Model desain sistem pembelajaran ini terlihat lebih sederhana jika dibandingkan dengan model desain sistem pembelajaran yang lain, seperti model Dick and Carey yang pada umumnya diimplementasikan pada sistem pembelajaran dengan skala yang lebih besar (Pribadi, 2009: 111). Model ASSURE dapat membuat siswa memahami materi pelajaran, hal ini dikarenakan anak tunalaras lebih memahami materi pelajaran dengan menggunakan media yang nyata. Beberapa penelitian lain telah membuktikan bahwa Mosel Pembelajaran ASSURE dapat meningkatkan prestasi belajar siswa. Namun model pembelajaran ASSURE belum pernah diterapkan dalam peningkatan prestasi belajar siswa tunalaras.

Hal tersebut membuat peneliti tertarik untuk meneliti lebih lanjut mengenai model pembelajaran ASSURE bagi anak tunalaras kelas IV di SLB E Bhina Putera Surakarta dengan mengambil judul pengaruh penggunaan model pembelajaran ASSURE terhadap peningkatan restasi belajar IPA anak tunalaras kelas IV di SLB E Bhina Putera Surakarta tahun Ajaran 2017/2018”. 


\section{METODE}

Penelitian dilaksanakan di SLB E Bhina Putera Surakarta pada bulan April 2018. Penelitian ini merupakan jenis penelitian eksperimen dengan one group pretest-posttest design. Pretest dan posttest dilakukan sebanyak satu kali, di antara pretest dan posttes terdapat intervensi menggunakan model pembelajaran assure yang dilakukan sebanyak enam kali. Subjek pada penelitian ini adalah 5 anak tunalaras kelas IV SLB E Bhina Putera Surakarta.

Variabel bebas dalam penelitian ini adalah penggunaan model pembelajaran assure dan variabel terikat adalah prestasi belajar IPA. Teknik pengumpulan data dilakukan melalui tes pilihan ganda dengan jumlah soal sebanyak 18 butir soal. Teknik uji validitas instrumen dan media menggunakan validitas isi yaitu validitas yang ditentukan oleh penilaian para ahli melalui beberapa tahapan, yaitu tahap pengamatan instrumen, tahap koreksi item dalam instrumen, dan tahap pertimbangan bagaimana instrumen menggambarkan cakupan substansi yang akan diukur.

Validitas isi dijadikan kriteria untuk menetapkan valid atau tidaknya isi dari variabel yang akan diukur. Teknik analisis data yang digunakan adalah analisis data kuantitatif non parametrik Wilcoxon Sign Rank Test yaitu teknik membandingkan antara hasil tes yang dilakukan sebelum diberikan intervensi dengan hasil tes setelah diberi intervensi. Perhitungan analisis data ini menggunakan bantuan aplikasi SPSS 23.

\section{HASIL DAN PEMBAHASAN}

Hasil penelitian meliputi data nilai pretest dan posttest subjek pada kegiatan yang telah dilaksanakan selama penelitian. Berdasarkan pretest yang telah dilaksanakan pada seluruh subjek penelitian, diperoleh data nilai prestasi belajar IPA anak tunalaras sebelum diberi intervensi menggunakan model pembelajaran ASSURE. Dari hasil pretest diketahui terdapat 4 siswa yang memiliki nilai yang sama yaitu RS dan RZ sebesar 38,89, RN dan RB sebesar 33,33. Dari nilai hasil pretest tersebut didapatkan presentase sebagai berikut, subjek dengan prestasi belajar sangat rendah adalah $0 \%$, subjek dengan prestasi belajar rendah adalah $80 \%$. Subjek dengan kemampuan yang cukup $0 \%$, sedangkan subjek dengan prestasi belajar baik $20 \%$ dan subjek dengan prestasi belajar sangat baik sebanyak $0 \%$.

Selain itu diketahui juga nilai rata-rata (mean), nilai tengah (median), nilai yang sering muncul (mode), skor tertinggi, skor terendah, dan simpangan baku (standar deviasi). Berdasarkan hasil perhitungan, dapat diketahui bahwa nilai rata-rata (mean) sebesar 57,77. Nilai tertinggi yang diperoleh adalah 77,78, sedangkan nilai terendah dari hasil posttest tersebut adalah 38,89 . Standar devisiasi dari hasil posttest adalah 16,94, sedangkan nilai tengah adalah 55,56 dan nilai yang sering muncul adalah 38,89 . 
Dari hasil data tersebut, data distribusi frekuensinya adalah sebagai berikut:

Tabel 1. Distribusi Frekuensi Nilai Pretest

\begin{tabular}{|c|c|}
\hline Valid & Frequency \\
\hline 33,33 & 2 \\
\hline 38,89 & 2 \\
\hline 61,11 & 1 \\
\hline Total & 5 \\
\hline
\end{tabular}

Berdasarkan gambar distribusi frekuensi nilai pretest menunjukan bahwa nilai awal anak bervariasi. Terdapat empat anak yang memiliki nilai yang sama yaitu 33,33 dan 38,89. Sedangkan satu subjek mendapat nilai berbeda dengan yang lain yaitu 61,11. Data nilai pretest tersebut dapat disajikan dalam bentuk histogram. Adapun bentuk histogram sebagai berikut:

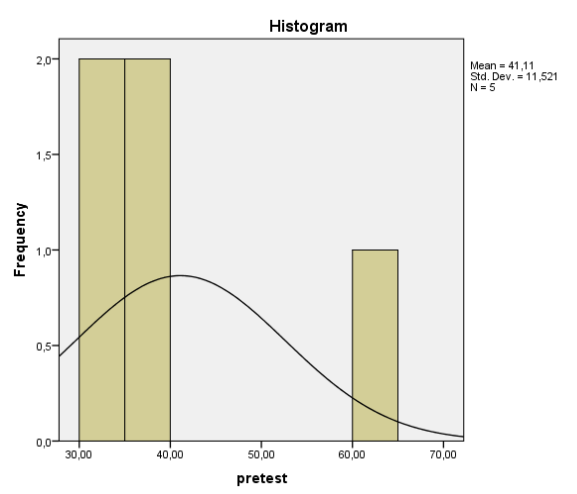

Gambar 1. Grafik Histogram Hasil Pretest

Kegiatan posttest bertujuan untuk mengetahui prestasi belajar IPA subyek setelah dilakukannya treatment yaitu dengan menggunakan model pembelajaran ASSURE. Berdasarkan posttest yang telah dilaksanakan pada seluruh subjek penelitian, diperoleh data nilai prestasi belajar IPA anak tunalaras setelah diberi intervensi menggunakan model pembelajaran ASSURE. Dari nilai hasil posttest tersebut didapatkan presentase sebagai berikut, subjek dengan prestasi belajar sangat rendah adalah $0 \%$, subjek dengan prestasi belajar rendah adalah $20 \%$, subjek dengan kemampuan yang cukup $40 \%$, sedangkan subjek dengan prestasi belajar baik $40 \%$ dan subjek dengan prestasi belajar sangat baik sebanyak $0 \%$.

Selain itu diketahui juga nilai rata-rata (mean), nilai tengah (median), nilai yang sering muncul (mode), skor tertinggi, skor terendah, dan simpangan baku (standar deviasi).

Diketahui bahwa nilai rata-rata (mean) sebesar 57,77. Nilai tertinggi yang diperoleh adalah 77,78, sedangkan nilai terendah dari hasil posttest tersebut adalah 38,89. Standar devisiasi dari hasil posttest adalah 16,94, sedangkan nilai tengah adalah 55,56 dan nilai yang sering muncul adalah 38,89. Dari hasil data tersebut, data distribusi frekuensinya adalah sebagai berikut: 
Tabel 2. Distribusi Frekuensi Nilai Posttest

\begin{tabular}{|c|c|}
\hline Valid & Frequency \\
\hline 38,89 & 1 \\
\hline 44,44 & 1 \\
\hline 55,56 & 1 \\
\hline 72,22 & 1 \\
\hline 77,78 & 1 \\
\hline Total & 5 \\
\hline
\end{tabular}

Berdasarkan tabel distribusi frekuensi nilai posttest menunjukan bahwa nilai anak bervariasi. Setiap subjek memiliki nilai yang berbeda. Nilai-nilai tersebut yaitu, 38,89, 44,44, 55,56, 72,22, dan 77,78. Data nilai posttest tersebut dapat disajikan dalam bentuk histogram. Adapun bentuk histogram sebagai berikut:

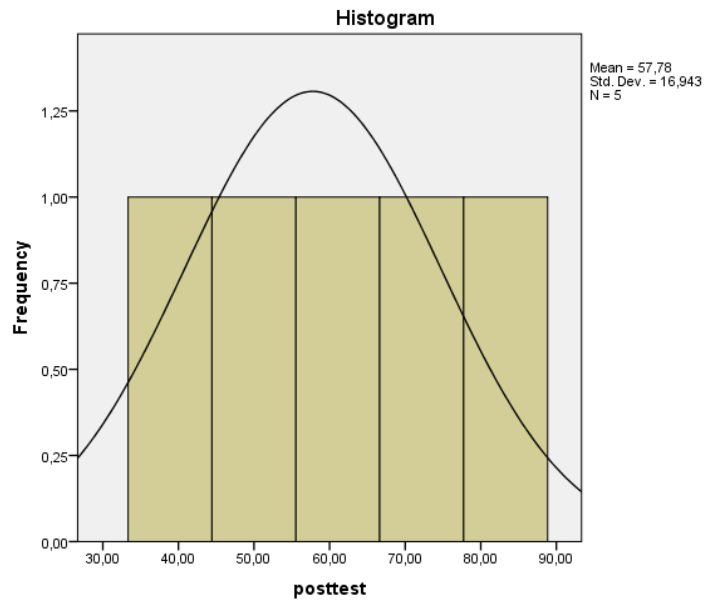

\section{Gambar 2. Grafik Histogram Hasil Posttet}

Perbandingan data antara nilai pretest dan posttest bertujuan untuk mengetahui pengaruh treatment dengan menggunakan model pembelajaran ASSURE terhadap peningkatan prestasi belajar IPA anak tunalaras kelas IV di SLB E Bhina Putera Surakarta tahun ajaran 2017/2018. Berikut tabel perbandingan nilai pretest dan posttest:

Tabel 3. Perbandingan Nilai Pretest dan Posttest

\begin{tabular}{|c|c|c|}
\hline $\begin{array}{c}\text { Nama } \\
\text { (Inisial) }\end{array}$ & Nilai Pretest & $\begin{array}{c}\text { Nilai } \\
\text { Posttest }\end{array}$ \\
\hline RS & 38,89 & 77,78 \\
\hline RN & 33,33 & 38,89 \\
\hline RZ & 38,89 & 44,44 \\
\hline RB & 33,33 & 55,56 \\
\hline DI & 61,11 & 72,22 \\
\hline Rata-rata & 41,11 & 57,77 \\
\hline
\end{tabular}


Berdasarkan hasil tabel tersebut, dapat diketahui adanya peningkatan nilai dari hasil pretest dan posttest. Peningkatan nilai yang terjadi pada rata-rata hasil pretest dan posttest adalah dari 41,11 menjadi 57,77.

Penelitian ini menggunakan analisis kuantitatif statistik non-parametrik dengan jenis analisis Wilcoxon Signed Rank Test untuk membuktikan hipotesis penelitian yang berbunyi "Model pembelajaran ASSURE berpengaruh terhadap peningkatan prestasi belajar IPA anak tunalaras kelas IV di SLB E Bhina Putera Surakarta tahun ajaran 2017/2018" dapat diterima atau tidak. Berikut hasil analisis Wilcoxon Signed Rank Test dengan menggunakan software SPSS 24:

\begin{tabular}{|c|c|c|c|c|}
\hline \multicolumn{5}{|c|}{ Ranks } \\
\hline & & $\bar{N}$ & $\begin{array}{l}\text { Mean } \\
\text { Rank }\end{array}$ & $\begin{array}{l}\text { Sum of } \\
\text { Ranks }\end{array}$ \\
\hline \multirow{4}{*}{$\begin{array}{c}\text { posttest - } \\
\text { pretest }\end{array}$} & $\begin{array}{c}\text { Negative } \\
\text { Ranks }\end{array}$ & $0^{\mathrm{a}}$ &, 00 & \multirow{4}{*}{15,00} \\
\hline & $\begin{array}{l}\text { Positive } \\
\text { Ranks }\end{array}$ & $5^{\mathrm{b}}$ & 3,00 & \\
\hline & Ties & $0^{c}$ & & \\
\hline & Total & 5 & & \\
\hline & $\begin{array}{l}\text { a. postt } \\
\text { b. postt } \\
\text { c. postt }\end{array}$ & $\begin{array}{l}<\text { pre } \\
>\text { pre } \\
=\text { pre }\end{array}$ & & \\
\hline
\end{tabular}

Gambar 3.Analisis Data Wilcoxon Signed Rank Test

Data yang diperoleh dari gambar menunjukkan bahwa hasil analisis Wilcoxon Signed Rank Test antara nilai pretest dan posttest tidak ada subjek yang memperoleh ranking negatif (negative rank), tidak terdapat pula subjek yang memiliki nilai yang sama (ties). Seluruh subjek memperoleh ranking positif (positive rank), sehingga dinyatakan seluruh subjek mengalami peningkatan nilai saat posttest dengan mean rank (ranking rata-rata) sebesar 3,00 dan sum of rank sebesar 15,00.

Proses perhitungan setelah menghitung ranking dari data pretest dan posttest, adalah perhitungan hasil tes. Perhitungan hasil tes juga menggunakan analisis Wilcoxon Signed Ranks Test. Berdasarkan perhitungan non parametrik Wilcoxon Signed Ranks Test akan didapatkan hasil Zhitung beserta Asymp. Sig (2-tailed) atau nilai P. Penelitian ini menggunakan taraf signifikansi $\alpha$ $=0,05$ atau $5 \%$. Berikut merupakan hasil perhitungan tes statistik : 


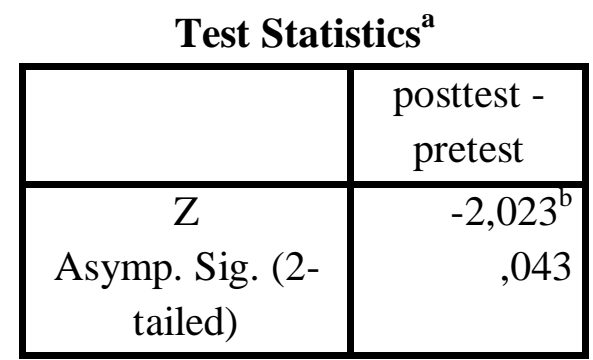

a. Wilcoxon Signed Ranks Test

b. Based on negative ranks.

Gambar 4. Hasil Tes Statistik

Perhitungan tes statistik tes statistik dari nilai pretest dan posttest memperoleh hasil Zhitung $=-2,027$ dengan Asymp. Sig. (2-tailed) =0,043. Nilai probabilitas dalam Zhitung kemudian dibandingkan dengan taraf signifikansi yang telah ditentukan yaitu $\alpha=0,05$.

Menurut hasil perhitungan tersebut, terdapat perbedaan yang signifikan antara hasil nilai pretest dan nilai posttest dengan nilai P sebesar 0,043 lebih kecil dari taraf signifikasi sebesar 0,05. Dengan demikian, dapat disimpulkan bahwa hipotesis penelitian yang berbunyi "Model pembelajaran ASSURE berpengaruh terhadap peningkatan prestasi belajar IPA anak tunalaras kelas IV di SLB E Bhina Putera Surakarta tahun ajaran 2017/2018” dapat diterima.

Hipotesis mengenai penggunaan model pembelajaran ASSURE berpengaruh terhadap peningkatan prestasi belajar pada mata pelajaran IPA materi gaya bagi siswa tunalaras kelas IV di SLB E Bhina Putera Surakarta dapat diterima kebenarannya. Hal tersebut dapat dilihat dari hasil analisis data yang menunjukkan bahwa, penggunaan model pembelajaran ASSURE dalam meningkatkan prestasi belajar pada mata pelajaran IPA materi gaya mengalami peningkatan setelah diberi perlakuan dibandingkan sebelum diberi perlakuan.

Peningkatan nilai tersebut dapat terjadi karena model pembelajaran yang berbasis gaya belajar siswa ini baru pertama kali diterapkan pada anak, sehingga cukup menarik perhatian anak. Model pembelajaran ASSURE memiliki sifat yang mengoptimalkan belajar dengan memanfaatkan media sehingga siswa lebih semangat mengikuti pembelajaran. Media yang digunakan dalam penelitian ini didesain sesuai dengan materi yang diajarkan, menggunakan media gambar, video, dan benda konkrit yang dapat menarik minat anak dan memudahkan anak dalam proses pembelajaran (pemberian treatment).

Model pembelajaran ASSURE merupakan salah satu model pembelajaran aktif yang melibatkan siswa secara langsung melalui kegiatan penelitian yang berkaitan dengan permasalahan sehari-hari anak. Menurut peneliti, penerapan model pembelajaran ASSURE dapat meningkatkan prestasi belajar IPA anak tunalaras. Menurut Zaini, dkk (2007: 5) pembelajaran yang aktif adalah suatu pembelajaran yang mengajak peserta didik untuk belajar secara aktif. Ketika peserta didik 
belajar dengan aktif, berarti mereka yang mendominasi aktivitas pembelajaran. Siswa yang aktif akan berpengaruh terhadap prestasi yang dicapai oleh siswa. Model ini dikembangkan untuk menciptakan aktivitas pembelajaran yang efektif dan efisien, khususnya pada kegiatan pembelajaran yang menggunakan media dan teknologi. Model ini, berorentasi pada KBM. Strategi pembelajarannya melalui pemilihan dan pemanfaatan metode, media, bahan ajar, serta peran serta pembelajar di lingkungan belajar. Sehingga ketika model ini diterapkan, siswa menjadi aktif dalam pembelajaran dan dapat meningkatkan prestasi belajar IPA mereka. Salah satu penelitian sebelumnya yang dilakukan oleh Prasetiyowati (2011) menyatakan bahwa model pembelajaran ASSURE dapat meningkatkan prestasi belajar akuntansi.

Pembelajaran yang menyenangkan maka belajar bukan merupakan sesuatu yang membosankan melainkan sesuatu yang disukai oleh anak sehingga materi pelajaran akan lebih terserap oleh anak karena anak tidak merasa terpaksa untuk belajar. Siswa akan lebih fokus dan menerima pelajaran dengan lebih cepat jika diberikan pengajaran yang menyenangkan, menghibur, dan menggugah minat dan hasrat siswa untuk mengikuti pembelajaran dengan baik. Materi yang terserap oleh anak menjadikan prestasi belajar IPA anak tunalaras menjadi meningkat.

\section{PENUTUP}

\section{Simpulan}

Berdasarkan pembahasan hasil penelitian pada bab IV, dapat diambil kesimpulan bahwa penggunaan model pembelajaran ASSURE berpengaruh terhadap peningkatan prestasi belajar IPA anak tunalaras kelas IV di SLB E Bhina Putera Surakarta tahun ajaran 2017/2018.

\section{Saran}

1. Bagi Siswa

a. Diharapkan siswa dapat mengoptimalkan prestasi belajar IPA pada saat penerapan model pembelajaran ASSURE.

b. Jika siswa mengalami kesulitan, diharapkan bertanya kepada guru yang mengajar atau teman sekelasnya.

2. Bagi Guru

Penggunaan model pembelajaran ASSURE hendaknya dijadikan sebagai alternatif bagi guru untuk meningkatkan prestasi belajar pada mata pelajaran IPA di kelas IV.

3. Bagi Penelitilain

Diharapkan peneliti lain dapat melakukan penelitian di SLB E di tempat yang berbeda sebagai pembanding dalam penelitian penggunaan model pembelajaran ASSURE untuk meningkatkan 
prestasi belajar anak tunalaras pada mata pelajaran IPA materi gaya kelas IV, sehingga diperoleh hasil yang lebih baik.

\section{DAFTAR PUSTAKA}

Direktorat Jenderal Manajemen Pendidikan Dasar dan Menengah. Direktorat Pembinaan Sekolah Luar Biasa. (2009)

Efendi, M. (2006).Pengantar Psikopedagogik Anak Berkelainan. Jakarta: PT Bumi Aksara

Prasetiowati. (2011). Peningkatan Prestasi Belajar Siswa pada Mata Pelajaran Akuntasi dengan Model ASSURE padaSiswa Kelas XI Ilmu Pengetahuan Sosial 4 SMA N 4 Surakarta. Skripsi. Universitas Sebelas Maret. Surakarta.

Pribadi, A. Benny. (2011). Model ASSURE untuk Mendesain Pembelajaran Sukses. Jakarta: PT Dian Rakyat

Smaldino, S.,dkk. (2011). Instructional Technology and Media for Learning: Teknologi Pembelajaran dan Media untuk Belajar. Jakarta: Kencana.

Sunardi. (1995). Ortopedagogik Anak Tunalaras I. Surakarta: Departemen Pendidikan dan Kebudayaan.

Somantri, T.S. (2007). Psikologi Anak Luar Biasa. Bandung: PT Refika Aditama.

Zaini, dkk. (2007). Strategi Pembelajaran Aktif. Yogyakarta: CTSD. 